\title{
Front Matter: Volume 7381
}

, "Front Matter: Volume 7381," Proc. SPIE 7381, International Symposium on Photoelectronic Detection and Imaging 2009: Material and Device Technology for Sensors, 738101 (8 September 2009); doi: 10.1117/12.846251

SPIE Event: International Symposium on Photoelectronic Detection and Imaging 2009, 2009, Beijing, China 


\title{
PROCEEDINGS OF SPIE
}

International Symposium on

Photoelectronic Detection and Imaging 2009

Material and Device Technology for Sensors

\author{
Xu-yuan Chen \\ Yue-lin Wang \\ Zhi-ping Zhou \\ Qing-kang Wang \\ Editors
}

17-19 June 2009

Beijing, China

Organized By

Tianjin Jinhang Institute of Technical Physics, CASIC (China)

Sponsored By

Photoelectric Technology Professional Committee, Chinese Society of Astronautics (China)

Published By

SPIE

Volume 7381 
The papers included in this volume were part of the technical conference cited on the cover and title page. Papers were selected and subject to review by the editors and conference program committee. Some conference presentations may not be available for publication. The papers published in these proceedings reflect the work and thoughts of the authors and are published herein as submitted. The publisher is not responsible for the validity of the information or for any outcomes resulting from reliance thereon.

Please use the following format to cite material from this book:

Author(s), "Title of Paper," in International Symposium on Photoelectronic Detection and Imaging 2009: Material and Device Technology for Sensors, edited by Xu-yuan Chen, Yue-lin Wang, Zhi-ping Zhou, Qing-kang Wang, Proceedings of SPIE Vol. 7381 (SPIE, Bellingham, WA, 2009) Article CID Number.

ISSN 0277-786X

ISBN 9780819476623

Published by

SPIE

P.O. Box 10, Bellingham, Washington $98227-0010$ USA

Telephone +1 3606763290 (Pacific Time) · Fax +1 3606471445

SPIE.org

Copyright (C) 2009, Society of Photo-Optical Instrumentation Engineers

Copying of material in this book for internal or personal use, or for the internal or personal use of specific clients, beyond the fair use provisions granted by the U.S. Copyright Law is authorized by SPIE subject to payment of copying fees. The Transactional Reporting Service base fee for this volume is $\$ 18.00$ per article (or portion thereof), which should be paid directly to the Copyright Clearance Center (CCC), 222 Rosewood Drive, Danvers, MA 01923. Payment may also be made electronically through CCC Online at copyright.com. Other copying for republication, resale, advertising or promotion, or any form of systematic or multiple reproduction of any material in this book is prohibited except with permission in writing from the publisher. The CCC fee code is 0277-786X/09/\$18.00.

Printed in the United States of America.

Publication of record for individual papers is online in the SPIE Digital Library.

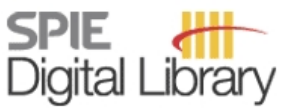

SPIEDigitalLibrary.org

Paper Numbering: Proceedings of SPIE follow an e-First publication model, with papers published first online and then in print and on CD-ROM. Papers are published as they are submitted and meet publication criteria. A unique, consistent, permanent citation identifier (CID) number is assigned to each article at the time of the first publication. Utilization of CIDs allows articles to be fully citable as soon they are published online, and connects the same identifier to all online, print, and electronic versions of the publication. SPIE uses a six-digit CID article numbering system in which:

- The first four digits correspond to the SPIE volume number.

- The last two digits indicate publication order within the volume using a Base 36 numbering system employing both numerals and letters. These two-number sets start with 00, 01, 02, 03, 04 , $05,06,07,08,09,0 A, 0 B \ldots 0 Z$, followed by 10-1Z, 20-2Z, etc.

The CID number appears on each page of the manuscript. The complete citation is used on the first page, and an abbreviated version on subsequent pages. Numbers in the index correspond to the last two digits of the six-digit CID number. 


\title{
Contents
}

\author{
xiii Symposium Committee \\ $\mathrm{xv}$ Conference Committee \\ xvii Introduction \\ xix Cooperating Organizations
}

\section{MATERIAL AND DEVICE TECHNOLOGY FOR SENSORS}

738102 Space optics remote sensor focusing components mechanics characteristic analysis based on FEM [7381-01]

Y. Wang, Changchun Institute of Optics, Fine Mechanics and Physics (China) and Graduate School of the Chinese Academy of Sciences (China); B. Wang, J. Ren, Changchun Institute of Optics, Fine Mechanics and Physics (China)

738103 ZnO-based material and UV detector [7381-02]

X. Wang, Changchun Univ. of Science and Technology (China); R. Xiang, Changchun Univ. of Science and Technology (China) and China Mechanical Equipment Research Academy (China); X. Zhang, J. Tian, Y. Li, D. Jiang, Q. Duanmu, Changchun Univ. of Science and Technology (China)

738104 Smart textile sensing system for human respiration monitoring based on fiber Bragg grating [7381-03]

C. Zhang, C. Miao, H. Li, H. Song, F. Xu, Tianjin Polytechnic Univ. (China)

738105 Brillouin-based distributed temperature and strain sensor using the Landau-Placzek Ratio [7381-04]

H. Fan, C. Huang, Y. Li, North China Electric Power Univ. (China)

738106 Design of a portable algae fluorometer based on an embedded system [7381-05] G. Yin, Y. Zhang, Anhui Institute of Optics and Fine Mechanics (China); Z. Wang, Yangzhou Univ. School of Environmental Science and Engineering (China); L. Guo, X. Xiao, D. Jin, N. Zhao, Anhui Institute of Optics and Fine Mechanics (China)

738107 Impact of $\mathrm{B}$-site $\mathrm{Hf}^{4+}$-doping on the structural and ferroelectric properties of $\mathrm{Bi}_{4} \mathrm{Ti}_{3} \mathrm{O}_{12}$ thin films [7381-06]

Y. Zhang, C. Zuo, X. Wang, J. Zhu, H. Ji, Univ. of Electronic Science and Technology of China (China)

738108 Effect of surface termination on the imaging in two-dimensional photonic crystal flat lenses [7381-07]

Z. Feng, G. Bai, Beijing Univ. of Chemical Technology (China) 
738109 The spatial detection on distribution of metal nano-particles during femtosecond laser ablation [7381-08]

N. Li, Tianjin Univ. of Technology and Education (China); X. Ni, Tianjin Univ. of Technology and Education (China) and Tianjin Univ. (China); R. Hong, Tianjin Univ. of Technology and Education (China); T. Donnelly, Trinity College Dublin (Ireland); X. Wang, S. Amoruso, Coherentia CNR-INFM, Univ. degli Studi di Napoli Federico II (Italy); C. Wang, Tianjin Univ. (China)

7381 OA Development of an image acquisition system for hand vein based on an embedded system [7381-09]

X. Li, T. Liu, Y. Wang, C. Yuan, S. Deng, Tianjin Univ. (China)

$7381 \mathrm{OB} \quad$ High thermal sensitivity of $\mathrm{Er}^{3+}$ and $\mathrm{Li}^{+}$codoped $\mathrm{Y}_{2} \mathrm{O}_{3}$ nanocrystals under $976 \mathrm{~nm}$ excitation [7381-10]

Y. Bai, Soochow Univ. (China) and Harbin Institute of Technology (China); Y. Wang, R. Yan, L. Yang, L. Liu, Harbin Institute of Technology (China); Y. Song, Soochow Univ. (China)

7381 OC Surface and electromechanical properties of polydimethylsiloxane films prepared by a modified molding technique [7381-11]

K. Wang, G. Ouyang, Vestfold Univ. College (Norway); L. Henriksen, PoLight Inc. (Norway); M. N. Akram, X. Chen, Vestfold Univ. College (Norway)

7381 OD Micro-motion exposure method based on PZT piezoelectric ceramics [7381-12] W. Sun, Harbin Normal Univ. (China); M. Zhang, Mudanjiang Teachers College (China); Z. Meng, Changchun Institute of Optics, Fine Mechanics and Physics (China)

7381 OE Raman scattering of Ino.82 Ga0.18As grown by two step technique [7381-13] T. Zhang, Hainan Normal Univ. (China); G. Miao, Changchun Institute of Optics, Fine Mechanics and Physics (China); J. Fu, H. Lin, F. Zhang, Hainan Normal Univ. (China); H. Song, Changchun Institute of Optics, Fine Mechanics and Physics (China)

7381 OF The case for electro-optic waveguide devices from ferroelectric $(\mathrm{Pb}, \mathrm{La})(\mathrm{Zr}, \mathrm{Ti}) \mathrm{O}_{3}$ thin film epilayers [7381-14]

$\varnothing$. Nordseth, J. Ø. Kjellman, C. C. You, Norwegian Univ. of Science and Technology (Norway); A. Røyset, SINTEF Materials and Chemistry (Norway); T. Tybell, J. K. Grepstad, Norwegian Univ. of Science and Technology (Norway)

$73810 G \quad$ The research on a photonic-crystal fiber sensor [7381-15]

Y. Peng, Y. Cheng, Dalian Maritime Univ. (China)

$7381 \mathrm{OH} \quad$ Optimum design for maximum wavelength resolution based on the edge filter ratiometric system [7381-16]

Q. Wu, G. Rajan, P. Wang, Y. Semenova, G. Farrell, Dublin Institute of Technology (Ireland)

7381 Ol Performance of $128 \times 128$ solar-blind AIGaN ultraviolet focal plane arrays [7381-17]

Y. Yuan, Y. Zhang, D. Liu, K. Chu, L. Wang, X. Li, Shanghai Institute of Technical Physics (China)

$73810 \mathrm{~J}$ Research on a wavelength demodulation algorithm in smart clothes based on FBG [7381-18]

H. Song, C. Miao, C. Zhang, H. Li, F. Xu, Tianjin Polytechnic Univ. (China) 
7381 OK Quantitative analysis of the spatial distortion of 3D integral image related to the mismatch of the microlens array [7381-19]

Q. Bu, X. Wang, Xidian Univ. (China); H. Bai, Xidian Univ. (China) and The Engineering College of Armed Police Force (China)

$7381 \mathrm{OL}$ Research on remote-controlling gate-ban system based on embedded system and GSM [7381-20]

Y. Chen, L. Sun, Guilin Univ. of Electronic Technology (China)

$7381 \mathrm{OM}$ Absorption and scattering of light by $\mathrm{VO}_{2}$ nanoparticle array [7381-21]

X. YU, Univ. of Shanghai for Science and Technology (China); Y. Li, Univ. of Shanghai for Science and Technology (China) and Shanghai Key Lab. of Modern Optical Systems (China); H. Wang, H. Zhang, W. Zhang, Y. Huang, Univ. of Shanghai for Science and Technology (China)

7381 ON Synthesis, structure, and electrochemical properties of nano-layered organic-inorganic perovskites containing $\mathrm{Fe}(\mathrm{CN})_{6}{ }^{3-}$ layers and its application for detection of DNA hybridization [7381-22]

J. Wu, H. Liu, Wuhan Univ. of Technology (China); Z. Lin, Wuhan Institute of Technology (China); M. Cao, Z. Yu, H. Hao, L. Guo, Wuhan Univ. of Technology (China)

738100 Strain measurement based on multimode fiber ring-down spectroscopy [7381-23] H. Qiu, G. Lai, Y. Wang, Y. Su, Longyan Univ. (China)

7381 OP Structural and optical properties of $\mathbf{M g}$-doped ZnO nanowires synthesized by electrodeposition [7381-24]

X. Fang, J. H. Li, Changchun Univ. of Science and Technology (China); D. X. Zhao, Changchun Institute of Optics, Fine Mechanics and Physics (China); X. H. Wang, Z. P. Wei, G. Y. Jin, Changchun Univ. of Science and Technology (China)

$7381 \mathrm{OQ}$ Optimal design and fabrication of ring resonator composed of $\mathrm{GeO}_{2}$-doped silica waveguides for IOG [7381-25]

L. Guo, B. Shi, C. Chen, H. Lv, Z. Zhao, M. Zhao, Changchun Univ. of Science and Technology (China)

7381 OR The Debye characteristic temperature of nanodiamond thin films [7381-26] Y. Wang, North China Electric Power Univ. (China); Q. Zhao, Hebei Univ. (China); Z. Zhao, Z. Yin, Q. Yang, H. Li, North China Electric Power Univ. (China)

7381 OS Finite element analysis of the deformable mirror [7381-27] F. Zhao, Beijing Technology and Business Univ. (China); P. Wang, Beijing Institute of Technology (China); Y. Gong, C. Meng, Y. Liu, Beijing Technology and Business Univ. (China)

7381 OT Photoelectricity signal processing circuit of interferometric fiber optic pressure sensor [7381-28]

Z. Guo, W. Li, Q. Meng, Y. Pan, G. Liu, F. Ge, Nankai Univ. (China); R. Zhang, Tianjin Vocational Institute (China)

7381 OU Research on packaging technology for a fiber optic acoustic sensor [7381-29]

R. Li, W. Xiao, D. Yao, B. Xu, L. Cong, Beihang Univ. (China) 
7381 OV Ohmic contacts to $n-G a N$ formed by ion-implanted Si into p-GaN [7381-30]

X. Bao, J. Xu, W. Zhang, L. Wang, K. Chu, C. Li, X. Li, Shanghai Institute of Technical Physics (China)

7381 OW A low-noise wide-dynamic-range UV detector with pixel-level A/D conversion [7381-31] W. Zhang, X. Bao, L. Wang, C. Li, Y. Yuan, X. Li, Shanghai Institute of Technical Physics (China)

7381 OX Liquid crystal cell design of VGA field sequential color LCoS display [7381-32]

Y. Liu, W. Geng, Y. Dai, Nankai Univ. (China)

7381 OY Investigation of GaN-based avalanche photodiodes [7381-33]

L. Wang, J. XU, Y. Yuan, P. Jiang, Y. Zhang, X. Li, Shanghai Institute of Technical Physics

(China)

$73810 Z \quad \mathrm{TiO}_{2}$ nanotube arrays for quantum dots sensitized solar cells [7381-34]

X. Wen, J. Tao, Y. Sun, Y. Sun, N. Dai, Shanghai Institute of Technical Physics (China)

738110 Effect of power on the structure and property of copper nitride films by DC reactive magnetron sputtering [7381-35]

X.-A. Li, Nanjing Univ. of Posts and Telecommunications (China) and Hubei Univ. for Nationalities (China); J.-P. Yang, Nanjing Univ. of Posts and Telecommunications (China);

A.-Y. Zuo, Z.-B. Yuan, Z.-L. Weng, X.-Y. Xiong, Hubei Univ. for Nationalities (China)

738111 Structural and optical properties of ZnO:Al thin films prepared by RF magnetron sputtering [7381-36]

Y. Gao, J. Ma, Z. Huang, Y. Hou, J. Wu, J. Chu, Shanghai Institute of Technical Physics (China)

738112 Optical properties of rubrene thin film grown by thermal evaporation [7381-37]

B. Yang, J. Deng, W. Zhao, Beijing Univ. of Technology (China)

738113 Nanocrystalline silicon quantum dots thin films prepared by magnetron reaction sputtering [7381-38]

W. Zhao, J. Deng, B. Yang, Beijing Univ. of Technology (China); Z. Yu, M. Aceves, Instituto Nacional de Astrofísica, Óptica y Electrónica (Mexico)

738114 The (1-x)Pb( $\left.\mathrm{Zn}_{1 / 3} \mathrm{Nb}_{2 / 3}\right) \mathrm{O}_{3} \times \mathrm{PPbTiO}_{3}$ nanograde film produced by improved LPE method [7381-105]

Y. Wan, Jiaxing Univ. (China) and Yunnan Normal Univ. (China); Y. WU, J. Zhang, Yunnan Normal Univ. (China); P. Yang, Zhejiang Univ. (China); L. Xiao, G. Yuan, Yunnan Normal Univ. (China); H. Yan, Zhejiang Univ. (China)

738115 Electrical and optical properties of $\mathrm{Mn}_{1.56} \mathrm{Co}_{0.96} \mathrm{Ni}_{0.48} \mathrm{O}_{4}$ films for infrared detection [7381-39] J. Wu, Z. M. Huang, Y. Hou, Y. Q. Gao, J. H. Chu, Shanghai Institute of Technical Physics (China)

738116 Research of fiber Bragg grating geophone based on cantilever beam [7381-40]

L. Wang, S. Chen, G. Tao, G. LU, K. Zhao, China Univ. of Petroleum (China) 
738117 Study on the preparation of vanadium oxide thin films by the metal-oxygenation method [7381-41]

T. Chen, M. Hu, J. Liang, J. Lu, L. Tan, Tianjin Univ. (China)

738118 Optical switching properties of $\mathrm{VO}_{\mathbf{x}}$ thin films deposited on $\mathrm{Si}_{3} \mathrm{~N}_{4}$ substrates using ion beam sputtering [7381-42]

J. Lu, M. Hu, J. Liang, T. Chen, L. Tan, Tianjin Univ. (China)

738119 Numerical calculation and simulation analysis of electrical field characteristics for the electrical resistance tomography system [7381-43]

Y. Zhang, D. Chen, L. Wang, Harbin Univ. of Science and Technology (China)

7381 lA A novel method for determination of particle size distribution in-process [7381-44]

T. A. Salaoru, M. Li, De Montfort Univ. (United Kingdom); D. Wilkinson, Heriot-Watt Univ. (United Kingdom)

7381 1B Growth of InGaSb quantum dots on GaAs substrate by molecular beam epitaxy [7381-106] Z. G. Li, Changchun Univ. of Science and Technology (China); M. H. You, Air Force Aviation Univ. (China); G. J. Liu, L. Lin, M. Li, Z. L. Qiao, Y. Deng, Y. Wang, X. H. Wang, Changchun Univ. of Science and Technology (China)

7381 1C Compound $\mathrm{TiO}_{2}$ nanocrystals synthesized by hydrothermal method [7381-45]

S. Liu, Agricultural Univ. of Hebei (China); S. Fu, Science and Technology Univ. of Henan (China); Y. Kang, Agricultural Univ. of Hebei (China)

7381 1D The controlling of microlens contour by adjusting developing time in the thermal reflow method [7381-46]

S. Di, R. Du, Shenzhen Institute of Advanced Integration Technology (China) and Chinese Univ. of Hong Kong (Hong Kong, China)

$7381 \mathrm{lE}$ The research and development of an air pollutant monitoring system based on DOAS technology [7381-47]

H. Li, H. Liu, M. Zheng, X. Meng, Beihang Univ. (China)

$7381 \mathrm{lF} \quad$ The intelligent design of the high power and energy laser measurement system [7381-48]

Y. Chang, J. Zhou, Beijing Univ. of Technology (China)

7381 1G Effect of deposition pressure on structural and optical properties of scandium-doped ZnO thin film prepared by sputtering [7381-49]

C. Miao, Z. Zhao, M. Li, Z. Ma, Shanghai Univ. (China)

7381 1H Nanocrystalline Si-based metal-oxide-semiconductor photodetectors [7381-50]

Z. Yu, M. Aceves-Mijares, Instituto Nacional de Astrofísica, Óptica y Electrónica (Mexico); J. A. Luna Lopez, Benemérita Univ. Autónoma de Puebla (Mexico); J. Deng, Beijing Univ. of Technology (China)

7381 1I A fiber optic sensor for on-line non-touch monitoring of roll shape [7381-51]

Y. Guo, W. Qu, Q. Yuan, Qi Qihaer Univ. (China)

7381 1 J Study on a novel type of CFBG vibration sensor [7381-52]

Q. Nan, Wuhan Univ. of Technology (China) 
$73811 \mathrm{~K} \quad$ Experimental study on the magneto-optical rotation enhanced effect [7381-53]

X. Shen, G. Bao, X. WU, Z.-C. Liang, Nanjing Univ. of Posts and Telecommunications (China)

7381 1L A novel device of dual-tuner variable-focus microlens [7381-54]

T. Chen, Z. Liang, R. Zhao, Nanjing Univ. of Posts and Communications (China)

$7381 \mathrm{lM}$ The research on the surface structure and conductivity of free-standing diamond films for photo-transistor applications [7381-55]

Y. Zhang, Q. Xiao, L. Wang, Q. Zeng, J. Huang, K. Tang, J. Zhang, J. Min, W. Shi, Y. Xia,

Shanghai Univ. (China)

7381 iN Preparation and photoelectric properties of a thin-film nanocrystalline diamond phototransistor [7381-56]

Q. Fang, L. Wang, Q. Zeng, J. Huang, J. Zhang, R. XU, W. Shi, Y. Xia, Shanghai Univ. (China)

738110 A DFB fiber laser sensor system using a NI-Compact-RIO-based PGC demodulation scheme [7381-57]

Y. Wang, J. He, L. Feng, F. Li, Y. Liu, Institute of Semiconductors (China)

7381 IP Study on strain transfer of polymer optical fiber grating sensors [7381-58]

X. Chang, M. Li, X. Gu, Xi'an Research Institute of High-tech (China); X. Han, Northwestern Polytechnical Univ. (China)

$7381 \mathrm{1Q}$ Research on a novel packaging structure and technology by red copper slice for fiber Bragg gratings [7381-59]

W. Wu, S. Li, W. Wang, Guangdong Ocean Univ. (China)

7381 IR The heterodyne research on transmission signal of three-layered cascaded long-period fiber gratings [7381-60]

Y. Wang, China Jiliang Univ. (China); K. Wang, Harbin Institute of Technology (China);

$X$. Wang, China Jiliang Univ. (China); S. Zhang, Harbin Engineering Univ. (China)

7381 is Study on fabrication of silicon microcantilevers for the pulse sensor by a laser etching technology [7381-61]

L. Wang, D. Wen, College of Heilongjiang Province (China) and Heilongjiang Univ. (China)

7381 1T Thermo-optic SOI waveguide switch matrix [7381-62]

Y. Chen, Beijing Technology and Business Univ. (China) and Institute of Semiconductors (China); Y. Li, Peking Univ. (China) and Institute of Semiconductors (China); J.-Z. Yu, Institute of Semiconductors (China)

$73811 \mathrm{U}$ Excimer pulsed laser deposition of diamond-like carbon films [7381-63]

Y. Guo, S. Wang, X. Wang, Y. Cheng, H. Wang, B. Sun, Wuhan Mechanical Technology

College (China)

7381 IV Study on the stabilization of an optical fiber interferometric sensor [7381-64]

J. Shao, J. Chen, Z. WU, Q. Tang, Third Research Institute of the Ministry of Public Security (China)

7381 IW MEMS resonator with digitally tunable resonant frequency [7381-65]

Q. Liu, Nanjing Univ. of Information Science and Technology (China) 
7381 1X Study on a transient optical fiber high temperature measurement system [7381-66]

L. Cai, Y. Liu, Y. Wang, Yanshan Univ. (China)

7381 1Y Characterization of wafer-level bonded hermetic packages using optical leak detection [7381-67]

A. Duan, K. Wang, K. Aasmundtveit, N. Hoivik, Vestfold Univ. College (Norway)

7381 IZ Fabrication and characterization of ZnO nanowires grown on Ti substrate [7381-68] G. Meng, X. Fang, R. Tao, W. Dong, Z. Deng, S. Zhou, Anhui Institute of Optics and Fine Mechanics (China)

738120 Pyroelectric properties of ZnO-based nanostructured polycrystalline ceramics [7381-69] R. Tan, Ningbo Univ. (China); Y.-L. Zhang, Y. Yang, W. Song, Ningbo Institute of Material Technology and Engineering (China); T. XU, Q. Nie, Ningbo Univ. (China)

$738121 \quad$ Study on fiber Bragg grating displacement sensing [7381-70]

L. Li, Tianjin Univ. of Technology (China); C. Ge, Tianjin Univ. (China)

738122 The data acquisition system design of a portable coordinate measuring machine [7381-71] Q. Ling, S. Liu, Z. Li, Tianjin Univ. (China)

738123 Effects of thermal oxidation interfacial layer on the photoelectrical properties of GaN-based Schottky diodes [7381-72]

K. Chu, C. Li, Y. Yuan, X. Li, Shanghai Institute of Technical Physics (China)

738124 Influence of Ag-doping on the microstructure and optical properties of $\mathrm{ZnO}$ nanoparticles [7381-73]

T. Xiong, D. Li, W. Shi, L. Wang, J. Huang, C. Wang, Shanghai Univ. (China)

738125 Survey of embedded OS specialized for a microsensor system [7381-74]

M. Yu, Univ. of Electronic Science and Technology of China (China); M. Cen, Chongaing Univ. of Posts and Telecommunications (China)

738126 Electrical characteristics of CuS/ZnO PN heterojunction [7381-75]

X. Qian, J. Fang, Y. Song, Suzhou Univ. (China)

738127 Research on a fiber Bragg grating sensor system with interferometric demodulation technique with LabVIEW [7381-76]

W. G. Qin, Northeast Dianli Univ. (China); Y. Zhang, Yanshan Univ. (China)

738128 Summary of semi-initiative and initiative control automobile engine vibration [7381-77]

W. Qu, Jilin Univ. (China); Z. Qu, Armor Technique Institute of PLA (China)

738129 High sensitivity glucose sensor based on optical heterodyne phase detection [7381-78]

J.-Y. Lin, National Changhua Univ. of Education (Taiwan); K.-H. Chen, J.-H. Chen, Feng Chia Univ. (Taiwan); Y.-C. Liao, Y.-H. Lin, National Changhua Univ. of Education (Taiwan)

7381 2A The research of a gyro-stabilized plafform and POS application technology in airborne remote sensing [7381-79]

J. Xu, Q. Du, Shanghai Institute of Technical Physics (China) 
$73812 B \quad$ Study on the performance of GaAs photoconductive semiconductor switches [7381-80] Y. Xie, W. Liu, Capital Normal Univ. (China); T. Lan, G. Ma, Beijing Institute of Technology (China); T. Guan, Capital Normal Univ. (China)

$73812 C \quad$ Refractive index controllable coatings for optical detectors [7381-81] J. Shen, S. Wang, X. Wang, Y. Liu, X. Li, Tongji Univ. (China)

$73812 \mathrm{D}$ Double crystal probe with one transmitter and multiple receivers for automatic inspection [7381-82]

Q. Liu, Peking Univ. (China); J. Liu, Anshan Kaida Nondestructive Testing Technology Co., Ltd. (China)

$73812 \mathrm{E} \quad$ Novel system for automatic measuring diopter based on ARM circuit block [7381-83] F. Xue, Univ. of Shanghai for Science and Technology (China); L. Zhong, Univ. of Shanghai for Science and Technology (China) and Shanghai Key Lab. of Modern Optical System (China); Z. Chen, D. Xue, Univ. of Shanghai for Science and Technology (China); X. Li, Univ. of Shanghai for Science and Technology (China) and Shanghai Key Lab. of Modern Optical system (China)

$73812 \mathrm{~F}$ The preparation of organic infrared semiconductor phthalocyanine gadolinium (III) and its optical and structural characterizations [7381-84]

L. Tang, R. Ji, L. Song, X. Chen, Y. Ma, Y. Wang, M. Qian, L. Song, H. Su, J. Zhuang, R. Yang, Kunming Institute of Physics (China)

$73812 \mathrm{G}$ Study on the optical properties of organic ultraviolet semiconductor KIP-OUVS-1 [7381-85] L. Tang, R. Ji, Y. Ma, X. Chen, L. Song, Y. Wang, L. Song, M. Qian, H. Su, J. Zhuang, R. Yang, Kunming Institute of Physics (China)

$73812 \mathrm{H} \quad$ Detection of Toxoplasma gondii with a DNA molecular beacon probe [7381-86] C. Zhou, S. Xu, J. Yang, J. Zhang, Z. Dai, G. Zheng, Tianjin Polytechnic Univ. (China); B. Sun, Nankai Univ. (China); S. Sun, Tianjin Univ. (China); T. Feng, Y. Zi, C. Liang, H. Luo, Tianjin Polytechnic Univ. (China)

$738121 \quad$ A new design and implementation of an infrared device driver in embedded linux systems [7381-87]

L. Jia, H. Cui, R. Wang, Shanghai Institute of Technical Physics (China)

$73812 \mathrm{~J} \quad$ Microreplication of flexible and stretchable polymer grating sensing elements for microstructural monitoring [7381-88]

Y. Liu, S. Zhang, China Jiliang Univ. (China); W. Tian, Xi'an Institute of Optics and Precision Mechanics (China)

$73812 \mathrm{~K} \quad$ Surface plasmon resonance and transmission enhancement on periodically patterned metal film [7381-89]

J. Zhang, X. Chen, W. Hu, Z. Li, W. Lu, Shanghai Institute of Technical Physics (China)

$73812 \mathrm{~L} \quad$ MEMS compressed tunable grating [7381-90]

$X$. Liu, Shanghai Institute of Microsystem and Information Technology (China) and Graduate School of the Chinese Academy of Sciences (China); T. Li, A. Ming, Y. Liu, P. Zhou, Y. Wang, Shanghai Institute of Microsystem and Information Technology (China) 
$73812 \mathrm{M}$ Integrated thermoelectric infrared sensor with $\mathrm{XeF}_{2}$ etching [7381-91]

D. XU, Shanghai Institute of Microsystem and Information Technology (China) and Graduate School of the Chinese Academy of Sciences (China); B. Xiong, Y. Wang, Shanghai Institute of Microsystem and Information Technology (China); M. Liu, Shanghai Institute of Microsystem and Information Technology (China) and Graduate School of the Chinese Academy of Sciences (China)

$73812 \mathrm{~N}$ Behavior simulation for electrically actuated bow-tie shaped fixed-fixed beams based on nodal analysis method [7381-92]

M. Li, Q. Huang, W. Li, Southeast Univ. (China)

738120 Nonlinear dynamics characterization of electrostatically actuated submicrobeam resonators [7381-93]

D. Yue, H. Yu, W. Yuan, Southeast Univ. (China)

$73812 \mathrm{P} \quad$ Modeling of measurement sensitivity of refractive index based on surface plasmon resonance of LPFGs [7381-94]

D. Ma, C. Wang, G. Zhang, M. Zhao, Soochow Univ. (China)

$73812 Q \quad$ Influence of flip chip solder bump distribution on MEMS sensor reliability [7381-95]

B. Wang, S. Wei, J. Tang, Southeast Univ. (China)

$73812 R \quad$ Modeling and analysis for moving plate with two-dimensional effect [7381-96]

T. Liu, W. Li, Q. Huang, Southeast Univ. (China)

$738125 \quad$ Modeling of wet adhesion of microstructures in shock environment [7381-97]

Z.-Z. Wang, Q.-A. Huang, J.-Y. Tang, Southeast Univ. (China)

$73812 T$ The effect from the substrate reflection to the inclined UV lithography of SU-8 photoresist [7381-98]

Z. Zhu, Q.-A. Huang, W.-H. Li, Z.-F. Zhou, Southeast Univ. (China)

$73812 \mathrm{U}$ Molecular dynamics study on Young's modulus of silicon nanostructures at finite temperature [7381-99]

Y. Wang, H. Yu, L. Lu, Y. Tan, Southeast Univ. (China)

$73812 \mathrm{~V}$ The design of optical fiber vortex flowmeter's probe [7381-100]

X. Lin, Y. Wang, Y. Ni, J. Li, Yanshan Univ. (China)

$73812 \mathrm{~W}$ Fabrication and photoelectrical properties of $\mathrm{AZO} / \mathrm{SiO}_{2} / \mathrm{p}$-Si heterojunction [7381-101] B. He, Z. Ma, Shanghai Univ. (China); Y. Shi, Kunming Institute of Physics (China); J. Xu, Wuhan Univ. of Technology (China); L. Zhao, F. Li, C. Shen, N. Zhang, L. Shen, X. Meng, C. Zhou, C. Miao, Shanghai Univ. (China)

$73812 \mathrm{X}$ In which sectors could new illumination technology strategically reduce $\mathrm{CO}_{2}$ emissions? [7381-102]

A. Bjarklev, J. Andersen, T. Kjaer, Roskilde Univ. (Denmark)

$73812 Y \quad$ Analytic evaluation of magnetic force of novel sensor [7381-103]

T. Wu, S. Yin, South China Univ. of Technology (China) 
$73812 Z$ Structural and electrical properties of delafossite $\mathrm{CuMO}_{2}(\mathrm{M}=\mathrm{Al}, \mathrm{Cr}, \mathrm{Y})$ semiconductors and their exploitation for ozone detection [7381-104]

Z. Deng, X. Fang, D. Li, R. Tao, W. Dong, T. Wang, S. Zhou, G. Meng, Anhui Institute of Optics and Fine Mechanics (China) and Key Lab. of Novel Thin Film Solar Cells (China); X. Zhu, Key Lab. of Novel Thin Film Solar Cells (China) and Institute of Solid State Physics (China)

Author Index 


\title{
Symposium Committee
}

\author{
Symposium Chairs
}

Liwei Zhou, Beijing Institute of Technology (China)

Guofan Jin, Tsinghua University (China)

Xun Hou, Xi' an Institute of Optics and Precision Mechanics (China)

Jiaxiong Fang, Shanghai Institute of Technical Physics (China)

Organizing Committee

Jinxue Wang, Chair, Raytheon Vision Systems (United States)

Yuping Cui, Chair, Beijing Institute of Automatic Control Equipment (China)

Zhixin Wu, Chair, Tianjin Jinhang Institute of Technical Physics (China)

Jianqiang Zhu, Shanghai Institute of Optics and Fine Mechanics

(China)

Wei Zhao, Xi' an Institute of Optics and Precision Mechanics (China)

Xiaopeng Wang, Xi'an Institute of Applied Optics (China)

Haimei Gong, Shanghai Institute of Technical Physics (China)

Quanxin Ding, Electro-Optical Equipment Research Institute, Aviation Industries of China (China)

Zhaojun Liu, Beijing Institute of Space Mechanics and Electricity (China)

Jungang Liu, The 44th Institute of China Electronic Technology Group Corporation (China)

Bo Liu, Beijing Huahang Radio Measurement and Research Institute (China)

Guoxiong Li, Key Laboratory of Control System Simulation, Beijing Simulation Center (China)

Xin Yu, Beijing Institute of Technology (China)

Huilin Jiang, Changchun University of Science and Technology (China)

Guangjun Zhang, Beijing University of Aeronautics and Astronautics (China)

Yu Yao, Harbin Institute of Technology (China)

Tianxu Zhang, Huazhong University of Science and Technology (China)

Suying Yao, Tianjin University (China)

Jun Shen, Tongji University (China)

Yuelin Wang, National Key Laboratory of Microsystem Technology (China)

Wei Wang, Beijing Aerospace Times Optical-electronic Technology Company, Ltd. (China) 
Program Committee

Guofan Jin, Chair, Tsinghua University (China)

Xuyuan Chen, Institute for Microsystem Technology, Norwegian Center of Expertise for Microsystems, Vestfold University College (Norway)

Yuelin Wang, Shanghai Institute of Microsystem and Information Technology (China)

Zhiping Zhou, Peking University (China)

Qingkang Wang, Shanghai Jiaotong University (China)

Farzin Amzajerdian, NASA Langley Research Center (United States)

Chunqing Gao, Beijing Institute of Technology (China)

Tianyu Xie, Peking University (China)

Jeffery Puschell, Raytheon Space Airborne Systems (United States)

Haimei Gong, Shanghai Institute of Technical Physics (China)

Jin Lu, Tianjin Jinhang Institute of Technical Physics (China)

Yi Cai, Shenzhen Compound Semiconductor Engineering Technology Research Institute (China)

Jindong Fei, Key Laboratory of Control System Simulation, Beijing Simulation Center (China)

Kun Zhang, The 44th Institute of China Electronic Technology Group Corporation (China)

Nick Waltham, Rutherford Appleton Laboratory (United Kingdom)

Guangjun Zhang, Beijing University of Aeronautics and Astronautics (China)

Kecong Ai, Key Laboratory for Low Light Level Technology of COSTIND (China)

Xiangjun Wang, Tianjin University (China)

X.-C. Zhang, Rensselaer Polytechnic Institute (United States)

James M. Ryan, University of New Hampshire (United States)

Cunlin Zhang, Capital Normal University (China)

Chuanxiang Tang, Tsinghua University (China)

Kangnan Qi, Beijing Optical Society (China)

Ying Gu, The General Hospital of the People's Liberation Army (China)

Yongtian Wang, Beijing Institute of Technology (China) 


\title{
Conference Committee
}

\author{
Conference Chairs
}

Xu-yuan Chen, Institute for Microsystem Technology, Norwegian Center of Expertise for Microsystems, Vestfold University College (Norway)

Yue-lin Wang, Shanghai Institute of Microsystem and Information Technology, CAS (China)

Zhi-ping Zhou, Peking University (China)

Qing-kang Wang, Shanghai Jiaotong University (China)

Program Committee

Jostein Grepstad, Norwegian University of Science and Technology

(Norway)

Koji Ishibashi, RIKEN (Japan)

Paul M. Koenraad, Eindhoven University of Technology (Netherlands)

H. C. Liu, National Research Council Canada (Canada)

Zhuo Sun, East China Normal University (China)

Xiao-wei Liu, Harbin Institute of Technology (China)

Qing-an Huang, Southeast University (China)

Xiang-yang Li, Shanghai Institute of Technical Physics, CAS (China)

Jian-jun He, Zhejiang University (China)

Xue-feng Wang, Beijing Aerospace Times Optical-electronic

Technology Company, Ltd. (China) 
Downloaded From: https://www.spiedigitallibrary.org/conference-proceedings-of-spie on 26 Apr 2023

Terms of Use: https://www.spiedigitallibrary.org/terms-of-use 


\section{Introduction}

We have the great honor of organizing the 3rd International Symposium on Photoelectronic Detection and Imaging (ISPDI) in Beijing, following the 1st and 2nd ISPDI held successfully in Beijing in 1993 and 2007. It is truly a great pleasure for us to greet more than 1,000 participants from many different countries attending ISPDI 2009! I firmly believe that the symposium will become an important international event in the field of photoelectronic detection and imaging technology.

ISPDI 2009 is sponsored by the Photoelectronic Technology Professional Committee and the Chinese Society of Astronautics, and is organized by Tianjin Jinhang Institute of Technical Physics. There are also 25 cooperating organizations that support the meeting. About 700 papers were accepted for presentation and 1,300 abstracts were submitted from more than 10 countries, including the United States, United Kingdom, Germany, France, Norway, Sweden, Demark, Canada, Japan, Republic of Korea, Russian Federation, China, and so on. We have over 90 internationally renowned scientists and experts who were invited to speak.

The purpose of ISPDI 2009 is to provide a forum for the participants to report and review the ideas, up-to-date comprehensive progress, and developments, and to discuss novel approaches to application areas in the field of photoelectronic detection and imaging. It is sincerely hoped that the research and development in photoelectronic detection and imaging will flourish, and that international cooperation of our the common interests will be enhanced.

I would like to heartily thank our sponsors and cooperative organizations for all they have done for the meeting. Thanks also to all the authors for their contributions to these proceedings, to all of the participants and friends for their interest and efforts in helping to make the symposium possible; to the organizing committee and the program committee for their effective work and valuable advice, especially the ISPDI 2009 Secretariat, and to the SPIE staff for their tireless effort and outstanding service in preparing and publishing the conference proceedings.

Again, we extend our warmest greetings to you and hope you have a rewarding and exciting stay during ISPDI 2009!

Liwei Zhou 
Downloaded From: https://www.spiedigitallibrary.org/conference-proceedings-of-spie on 26 Apr 2023

Terms of Use: https://www.spiedigitallibrary.org/terms-of-use 


\title{
Cooperating Organizations of ISPDI 2009
}

\author{
Shanghai Institute of Microsystem and Information Technology (China) \\ Shanghai Institute of Optics and Fine Mechanics, CAS (China) \\ Xi' an Institute of Optics and Precision Mechanics, CAS (China) \\ Shanghai Institute of Technical Physics, CAS (China) \\ Xi' an Institute of Applied Optics (China) \\ Beijing Institute of Automatic Control Equipment (China) \\ Electro-Optical Equipment Research Institute of AVIC (China) \\ Beijing Institute of Space Mechanics and Electricity (China) \\ The 44th Institute of China Electronic Technology Group Corporation (China) \\ Beijing Huahang Radio Measurement and Research Institute (China) \\ State Key Laboratory of Transient Optics and Photonics (China) \\ Key Laboratory for Low Light Level Technology, COSTIND (China) \\ Key Laboratory of Control System Simulation, Beijing Simulation Center (China) \\ State Key Laboratory of Transducer Technology (China) \\ National Key Laboratory of Microsystem Technology (China) \\ Tsinghua University (China) \\ Beijing Institute of Technology (China) \\ Beijing University of Aeronautics and Astronautics (China) \\ Harbin Institute of Technology (China) \\ Huazhong University of Science and Technology (China) \\ Tongji University (China) \\ Changchun University of Science and Technology (China) \\ Capital Normal University (China) \\ The National Training Base for Integrated Circuits, Tianjin University (China) \\ Simulation Methodology and Modeling Professional Committee, Chinese \\ Association for System Simulation (China) \\ Beijing Aerospace Times Optical-Electronic Technology Company, Ltd. (China)
}


Downloaded From: https://www.spiedigitallibrary.org/conference-proceedings-of-spie on 26 Apr 2023

Terms of Use: https://www.spiedigitallibrary.org/terms-of-use 